\title{
Chronic Granulomatous Disease: Mode of Action of Sulfamethoxazole/Trimethoprim
}

\author{
FELIX K. GMÜNDER AND REINHARD A. SEGER ${ }^{(48)}$ \\ Department of Pediatrics, Division of Hematology-Immunology University of Zürich, Zürich, Switzerland
}

Dedicated to Professor W. H. Hitzig on his 60th birthday

\begin{abstract}
Summary
Four possible modes of action for the clinically observed effectiveness of sulfamethoxazole/trimethoprim in chronic granulomatous disease were evaluated: (1) inhibition of bacterial catalase, (2) improvement of granulocyte oxygen metabolism, (3) synergism of the antibiotic with nonoxygen-dependent granulocyte killing mechanisms, and (4) a purely antibiotic effect based on uptake and concentration of the antibiotic by and within granulocytes.

While the first three mechanisms were excluded, the fourth mechanism is highly probable; sulfamethoxazole was found to reach granulocyte associated concentrations 1.7 -fold and trimethoprim 4.1-fold of extracellular levels. Penicillin G, a known nonpenetrating antibiotic, reached 0.3-fold, and tetracycline, a known penetrating agent, 7.1-fold the extracellular level. These findings indicate that sulfamethoxazole/trimethoprim is an antibiotic combination uniquely suited for the long-term prophylaxis of infections in patients with defects of intracellular phagocyte killing.
\end{abstract}

\section{Speculation}

Cell permeable antibiotics that concentrate within the acidic granules and vacuoles of phagocytes are likely to be lipid-soluble weak bases.

Chronic granulomatous disease (CGD) is an inherited disease characterized by recurrent and sometimes fatal infections due to a metabolic defect of the polymorphonuclear leukocytes (PMN). CGD-PMN are deficient in one or several metabolic steps necessary to generate oxygen radicals including hydrogen peroxide which, together with myeloperoxidase and chloride, forms a microbicidal complex in the phagocytic vacuole (21). This deficiency of oxygen radicals and hydrogen peroxide in CGD-PMN results in the survival of ingested catalase positive $(19,28,34)$, but not of catalase negative bacteria (e.g., streptococci, lactobacilli, obligate anaerobic bacteria). Although both groups of organisms generate hydrogen peroxide, release of hydrogen peroxide into the vacuole and subsequent restoration of the microbicidal complex is possible only in the absence of bacterial catalase. The complex can also be restored by other peroxide generating systems or by added $\mathrm{H}_{2} \mathrm{O}_{2}$ $(17,36)$.

Early attempts to treat the persistent infections in CGD failed (33) until the advent of antibiotic therapy. Although nafcillin and rifampicin are effective $(13,26,33)$, to date most physicians use a sulfonamide or preferentially sulfamethoxazole/trimethoprim (SMX/TMP) not only for acute infections, but also for long term prophylaxis $(1,7,18,24,29,35,42)$ with one reported failure $(26)$. Since then the frequency and severity of bacterial infections in CGD have been substantially reduced.

Apart from previous investigations by Johnston et al. (18), who showed improved in vitro bacterial killing by CGD-PMN after the addition of sulfisoxazole, the use of SMX/TMP in CGD is purely empiric. Since the low frequency of the disease $\left(1: 10^{6}\right)$ precludes clinical studies, it was decided to elucidate the mechanisms involved by in vitro experiments. Four possible modes of action were evaluated. (1) Inhibition of bacterial catalase by SMX/TMP or one of its metabolites allowing hydrogen peroxide of microbial origin to diffuse out of the bacteria and to restore the deficient bactericidal complex in CGD-PMN. (2) Improvement of oxygen metabolism in CGD-PMN or direct generation of hydrogen peroxide by SMX/TMP or one of its metabolites. (3) Synergistic action between nonoxygen-dependent PMN killing mechanisms (normal in CGD) and SMX/TMP. (4) A purely antimicrobial effect of SMX/TMP on ingested bacteria dependent on intracellular concentration of the antibiotic as the result of a favourable partition coefficient. Bacteria, resistant to serum levels of the antibiotic, would then be inhibited or killed after phagocytosis.

\section{MATERIALS AND METHODS}

\section{ISOLATION OF PMN}

PMN were obtained from 10 healthy volunteers and three CGD patients. Informed consent of the donors was obtained before the start of this investigation.

PMN were separated from heparinized blood by dextran and ficoll-hypaque sedimentation (6), and resuspended in modified Krebs-Ringer phosphate buffer (KRP): $16 \mathrm{mM}$ sodium phosphate $120 \mathrm{mM} \mathrm{NaCl}, 5 \mathrm{mM} \mathrm{KCl}, 0.9 \mathrm{mM} \mathrm{CaCl}_{2}, 1.2 \mathrm{mM} \mathrm{MgSO}$ and $4 \mathrm{~g} \mathrm{liter}^{-1}$ human serum albumin. The $\mathrm{pH}\left(\mathrm{pH} 7.4\right.$ at $\left.37^{\circ} \mathrm{C}\right)$ was adjusted with $1 \mathrm{M} \mathrm{NaOH}$ and $1 \mathrm{M} \mathrm{HCl}$. Cell counts were performed in a Coulter counter. The normal PMN remained intact and functional for at least $4 \mathrm{~h}$ after isolation, as determined routinely by latex particle-induced metabolic burst and by bacterial killing tests. Viability of the CGD-PMN was established by stimulation of the metabolic burst with phenazine methosulfate.

\section{OXYGEN CONSUMPTION}

Oxygen metabolism before and after latex particle stimulation was recorded on an oxygraph (Gilson, model 5/6), according to Segal and Coade (40). The reaction mixture contained in a final volume of $1.6 \mathrm{ml} \mathrm{KRP}$ (reaction temperature $37^{\circ} \mathrm{C}$ ) $5 \times 10^{6} \mathrm{ml}^{-1}$ PMN. Latex particles $2.5 \times 10^{8} \mathrm{ml}^{-1}$ (Difco, dialysed against KRP) served to initiate the metabolic burst. Oxygen consumption during the following 4-8 min was used to calculate the stimulated consumption as nmol $\mathrm{O}_{2}$ per $\mathrm{h}$ per $5 \times 10^{6} \mathrm{PMN}$. The oxygraph was calibrated with air-saturated water, in which $210 \mu \mathrm{M}$ oxygen are dissolved at $37^{\circ} \mathrm{C}$ and $101.3 \mathrm{kPa}(10)$.

\section{GENERATION OF $\mathrm{H}_{2} \mathrm{O}_{2}$}

Generation of hydrogen peroxide by SMX/TMP or one of its metabolites in human serum was investigated in an oxygraph after the addition of ascorbate. Serum was obtained from normal volunteers before and $3 \mathrm{~h}$ after oral administration of SMX/TMP $18 \mathrm{mg} \mathrm{kg}^{-1}$ body weight and was heated at $62^{\circ} \mathrm{C}$ for one $\mathrm{h}$ to 
inactivate endogenous catalase. Similar experimental conditions have been described by Deamer et al. (9) for the production of hydrogen peroxide by the alloxan-dialuric acid cycle.

\section{CATALASE ACTIVITY}

Catalase activity was assayed in an oxygraph as described by Del Rio et al. (10). Bacteria were preincubated for $3 \mathrm{~h}$ in the test media $\left(10^{5}\right.$ cells $\left.\mathrm{ml}^{-1}\right)$ and were then transferred to an oxygraph. When a stable base line was established, hydrogen peroxide ( 9 $\mathrm{mM}$ end-concentration) was added and oxygen liberation was then recorded during the next $10 \mathrm{~min}$.

\section{GENERATION OF $\mathrm{O}_{2}$}

Superoxide $\left(\mathrm{O}_{2}{ }^{-}\right)$production was stimulated by addition of $\mathrm{NaF}$ ( $20 \mathrm{mM}$ end-concentration), and measured by superoxidedismutase-inhibitable reduction of ferricytochrome $\mathrm{C}$ using the technique described by Babior et al. (3).

\section{PREPARATION OF GRANULE-RICH FRACTION (GFR)}

Purified PMN from $400 \mathrm{ml}$ of blood of a healthy volunteer were homogenized according to Dewald et al. (11) in $0.1 \mathrm{M}$ Sörensen buffer, $\mathrm{pH} 7.4$ at $4^{\circ} \mathrm{C}$ and $0.34 \mathrm{M}$ sucrose. The postnuclear supernatant $(1000 \times \mathrm{g}, 5 \mathrm{~min})$ was centrifuged for $20 \mathrm{~min}$ at 15,000 $\times g$. The sediment contained, besides other cell organelles, abundant cytoplasmic granules and was designated as the GRF (4). The membranes of the GRF were lysed with $0.02 \%(v / v)$ triton X 100 and the lysate stored in small quantities in liquid nitrogen. Under these conditions microbicidal activity is maintained for at least 4 wk.

\section{MICROORGANISMS}

Staphylococcus aureus strains (KS 1, SMX/TMP resistent and KS 2, SMX/TMP suceptible, both isolated from patients) were maintained on Columbia sheep blood agar (Gibco) and subcultured monthly. For routine experiments, the bacteria were grown in two passages in Isosensitest broth (Oxoid) in a shaking water bath. Determination of colony forming units (CFU) was done as described by Meynell and Meynell (30).

\section{SYNERGISTIC ACTION OF SMX/TMP WITH GRF}

Staphylococci (about $10^{5} \mathrm{ml}^{-1}$ ) were incubated in broth at $\mathrm{pH}$ 7.4 or 6.0 . Antimicrobials and/or GRF were added at minimal

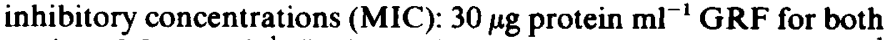
strains, $0.2 \mu \mathrm{g} \mathrm{ml}^{-1}$ flucloxacillin for both strains, $50 \mu \mathrm{g} \mathrm{ml}^{-1}$ SMX/TMP (5: l, by weight) for strain KSI and $1.5 \mu \mathrm{g} \mathrm{ml}^{-1}$ SMX/ TMP (5:1, by weight) for strain KS2.

\section{CELL PENETRATION OF ANTIBIOTICS}

According to the method of Mandell (27) PMN/buffer partition coefficients were determined. Buffer was used instead of serum to avoid PMN aggregation. The cells were incubated for $1 \mathrm{~h}$ in KRP

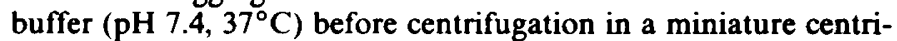
fuge (Microfuge B; Beckman Instruments). During this time they were exposed to radioactive-labelled antibiotics at concentrations obtainable in vivo: SMX $24 \mu \mathrm{g} \mathrm{ml}^{-1}$, TMP $5 \mu \mathrm{g} \mathrm{m}^{-1}$, Penicillin $\mathrm{G} 12 \mu \mathrm{g} \mathrm{ml}^{-1}$, and tetracycline $1 \mu \mathrm{g} \mathrm{ml}^{-1}$. Total and extracellular water spaces in the PMN sediment were assayed with ${ }^{3} \mathrm{H}_{2} \mathrm{O}$ and $\mathrm{l}^{14} \mathrm{C}$-carboxyinulin, respectively (38), and the intracellular water space calculated as their difference. Intracellular antibiotic concentration was calculated from extracellular antibiotic concentration (assumed to be identical with the concentration in the supernatant) and intra- and extracellular water spaces in the sediment. Partition coefficients were then expressed as concentration of the antibiotic in the water space of the PMN divided by the concentration in the KRP phase. Radioactive-labeled compounds were obtained from New England Nuclear $\left({ }^{3} \mathrm{H}_{2} \mathrm{O},\left[{ }^{14} \mathrm{C}\right]\right.$-carboxyinulin and tetracycline $\left[7-{ }^{3} \mathrm{H}(\mathrm{N})\right]$, Amersham Radiochemical Centre $\left(\left[{ }^{14} \mathrm{C}\right]\right.$-benzylpenicillin $=$ potassium 6 -phenyl- $1-\left[{ }^{14} \mathrm{C}\right]$ acetamidopenicillanate and $\left[{ }^{35} \mathrm{~S}\right]$-sulfamethoxazole $=3-\left[{ }^{35} \mathrm{~S}\right]$ sulfanilamido5-methylisoxazole) and Wellcome Research Laboratories $\left(\left[{ }^{14} \mathrm{C}\right]-\right.$ trimethoprim $=2,4$-diamino-5-(3,4,5-trimethoxybenzyl)-2- $\left[{ }^{14} \mathrm{C}\right]$ pyrimidine).

\section{RESULTS}

\section{INHIBITION OF BACTERIAL CATALASE}

The results are summarized in Table 1. Bacterial catalase activity remained unchanged when two strains of $S$. aureus were incubated for $3 \mathrm{~h}$ in (1) buffer (2) buffer with SMX/TMP, (3) human serum, heat inactivated, and (4) human serum obtained 3 $\mathrm{h}$ after oral SMX/TMP administration $\left(18 \mathrm{mg} \mathrm{kg}^{-1}\right)$ and heat inactivated. Serum concentrations of antimicrobials were in the range of $40-60 \mu \mathrm{g} \mathrm{ml}^{-1}$ for SMX and 2-3 $\mu \mathrm{g} \mathrm{ml}^{-1}$ for TMP. Serum bacteriostatic tests before and after heat inactivation showed no loss of antibiotic activity. In contrast to SMX/TMP, azide and cyanide at $0.1 \mathrm{mM}$ completely inhibited the bacterial catalase under the same assay conditions.

\section{IMPROVEMENT OF GRANULOCYTE OXYGEN METABOLISM}

There was no improvement of oxygen uptake by resting and stimulated PMN (four normal and two CGD donors) (Table 2) after the in vitro addition of SMX/TMP in KRP $\left(120 \mu \mathrm{g} \mathrm{ml}^{-1}\right)$ or of human serum after SMX/TMP administration (see above). Normal or CGD-PMN (three donors each) isolated $3 \mathrm{~h}$ after oral administration of SMX/TMP in various doses did not show an increase in stimulated superoxide production (Table 3 ). When ascorbate was added to heat inactivated serum drawn before and $3 \mathrm{~h}$ after oral administration of SMX/TMP (Fig. $\mathrm{l} b$ and $\mathrm{lc}$ ) there was no generation of hydrogen peroxide. This contrasted with hydrogen peroxide generation by the ascorbate driven oxidation of dialuric acid to alloxan (Fig. $1 a$ ).

\section{SYNERGISTIC ACTION OF SMX/TMP WITH GRF}

As shown in Fig. 2, growth of staphylocci without GRF or antibiotics was exponential for strain $\mathrm{KS}$, which is clinically resistant to SMX/TMP (MIC for SMX/TMP, flucloxacillin and GRF see "Materials and Methods"), or nearly exponential for strain KS2, which is clinically susceptible to SMX/TMP (see also "Materials and Methods"), during the first $6 \mathrm{~h}$ of incubation. The growth was unaffected by Triton X 100 (which was used in the same concentrations as those resulting from the addition of tritonlysed GRF to the broth). Addition of 1.0 MIC of either GRF (isolated from normal PMN of a single volunteer), flucloxacillin or SMX/TMP alone inhibited the growth of both strains. While

Table 1. Catalase activity of $S$. aureus: influence of $S M X / T M P$

\begin{tabular}{|c|c|c|}
\hline \multirow{3}{*}{ Medium } & \multicolumn{2}{|c|}{ Catalase activity } \\
\hline & \multicolumn{2}{|c|}{ (nmoles $\mathrm{H}_{2} \mathrm{O}_{2} 10^{-5}$ cells $\min ^{-1}$ ) } \\
\hline & S. aureus KS1 & S. aureus KS2 \\
\hline KRP buffer & $11.5 \pm 0.6^{1}$ & $19.4 \pm 0.2^{1}$ \\
\hline $\begin{array}{l}100 \mu \mathrm{g} \mathrm{ml}^{-1} \mathrm{SMX} \text { and } 20 \\
\mu \mathrm{g} \mathrm{ml}^{-1} \mathrm{TMP}^{2} \text { in KRP } \\
\text { buffer }\end{array}$ & $11.6 \pm 0.9$ & $19.1 \pm 0.8$ \\
\hline $\begin{array}{l}\text { Heat inactivated }{ }^{3} \text { human } \\
\text { serum before SMX/ } \\
\text { TMP administration }\end{array}$ & $11.6 \pm 0.8$ & $19.8 \pm 0.6$ \\
\hline $\begin{array}{l}\text { Heat inactivated }{ }^{3} \text { human } \\
\text { serum } 3 \mathrm{~h} \text { after SMX/ } \\
\text { TMP administration }\end{array}$ & $11.0 \pm 0.8$ & $19.8 \pm 0.8$ \\
\hline Cyanide or azide $0.1 \mathrm{mM}$ & 0 & 0 \\
\hline
\end{tabular}

\footnotetext{
'Mean \pm S.D. $(n=4)$.

${ }^{2}$ Corresponds to $0.4 \mathrm{mM}$ SMX and $0.07 \mathrm{mM}$ TMP.

${ }^{3} 62^{\circ} \mathrm{C}$, lh.
} 
Table 2. Oxygen consumption of normal and CGD-PMN: influence of SMX/TMP

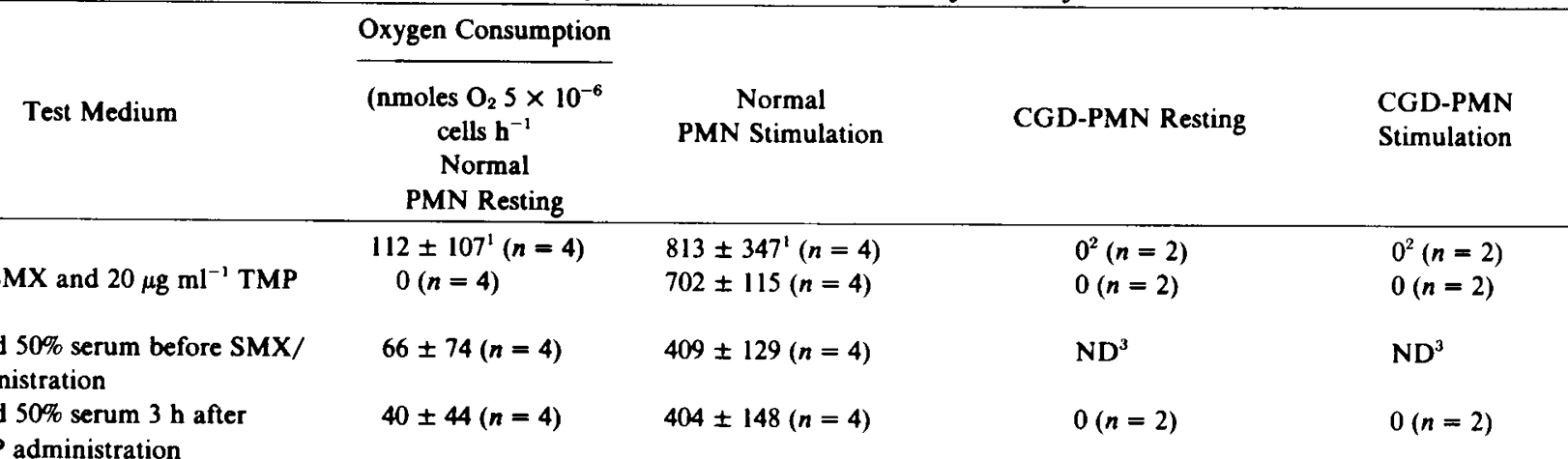

${ }^{1}$ Mean \pm S.D.

2 Values, mean.

${ }^{3} \mathrm{ND}=$ not done.

Table 3. Stimulated superoxide production of normal and CGD PMN: influence of SMX/TMP

\begin{tabular}{|c|c|c|c|c|}
\hline \multirow[b]{2}{*}{ PMN } & \multirow[t]{2}{*}{ Dose of SMX/TMP } & \multicolumn{2}{|c|}{ Stimulated $\mathrm{O}_{2}^{-}$-production } & Serum level of SMX/TMP \\
\hline & & $\begin{array}{c}\text { (nmoles } \mathrm{O}_{2}^{-} \\
\text {Before } \\
\text { SMX/TMP }\end{array}$ & $\begin{array}{c}\text { cells } \min ^{-1} \text { ) } \\
3 \mathrm{~h} \text { after } \\
\text { SMX/TMP }\end{array}$ & $\left(\mu \mathrm{g} \mathrm{ml}^{-1}\right)$ \\
\hline $\mathrm{a}^{2} \cdot \mathrm{CGD}$ & 18 & $3.7^{1}$ & 0.8 & 30.2 \\
\hline Control & 18 & 19.8 & 26.4 & \\
\hline b. CGD & 28 & 0.5 & 2.0 & 75.7 \\
\hline Control & 28 & 36 & 35.2 & \\
\hline c. $\mathrm{CGD}$ & 48 & 1.6 & 1.1 & 82.5 \\
\hline Control & 48 & 26.6 & 33.7 & \\
\hline
\end{tabular}

'Values, mean.

${ }^{2}$ Three different CGD patients.

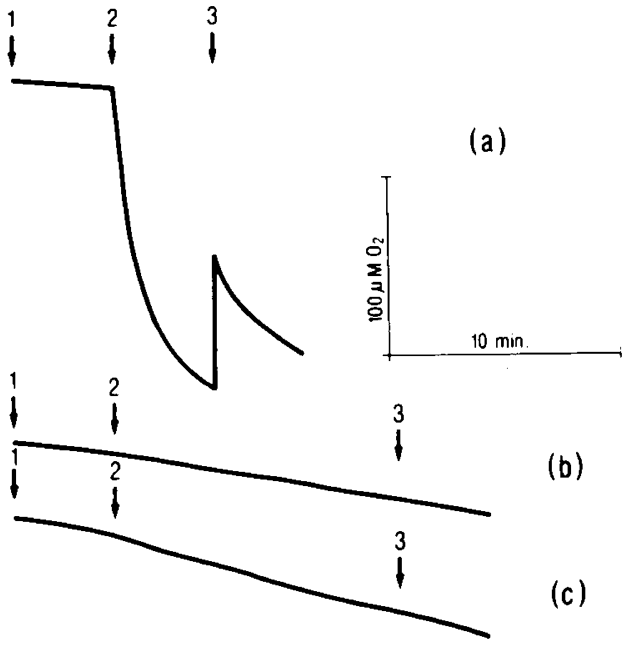

Fig. 1. Oxygraph tracings showing lack of generation of hydrogen peroxide in human serum before (b), and after (c) SMX/TMP administration. Production of hydrogen peroxide by the alloxandialuric cycle $(a)$ served as a control. Addition of $0.5 \mathrm{M}$ alloxan in buffer or of human serum (1), addition of $0.5 \mathrm{mM}$ ascorbate (2), and addition of $80 \mu \mathrm{g} \mathrm{ml}^{-1}$ bovine catalase (3).

the combination of flucloxacillin and GRF resulted in killing, the combination of SMX/TMP and GRF produced no change. Results from experiments at $\mathrm{pH} 6.0$ are not shown, as they did not differ from the values at $\mathrm{pH} 7.4$.

\section{CELL PENETRATION OF ANTIBIOTICS}

The results (obtained with normal PMN) are summarized in Table 4. Except for penicillin $G$ all antibiotics (SMX, TMP,

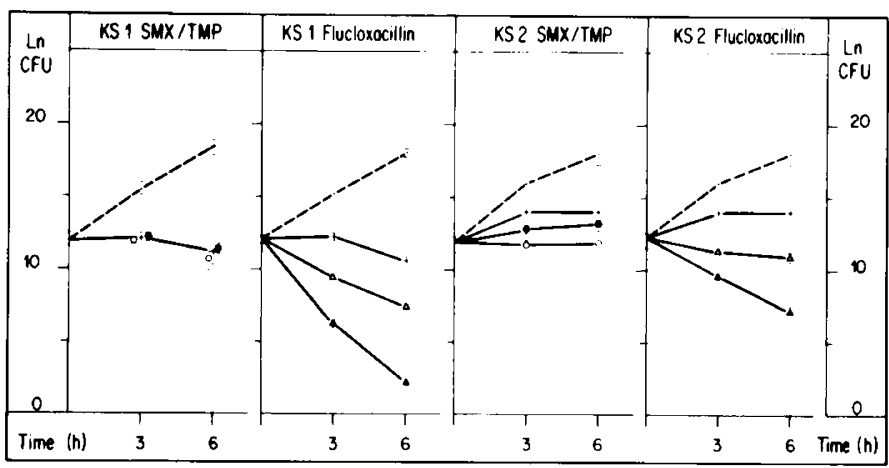

Fig. 2. Lack of synergistic action of SMX/TMP with GRF $(a, c)$ as opposed to synergism of flucloxacillin with $\operatorname{GRF}(b, d)$. GRF was obtained from normal PMN (Material and Methods). Growth without inhibitors (. . . . .), with $1.0 \mathrm{MIC}$ GRF (-+-), with $1.0 \mathrm{MIC}$ SMX/TMP $(-$ ) with $1.0 \mathrm{MIC}$ flucloxacillin $(-\Delta-)$, and with both, $1.0 \mathrm{MIC}$ GRF and either SMX/TMP (- - ) or flucloxacillin (- - - ). Strain KS1 has a MIC of $50 \mu \mathrm{g} \mathrm{ml}^{-1} \operatorname{SMX} / \mathrm{TMP}$ (5:1, by weight), strain KS2 has MIC of $1.5 \mu \mathrm{g} \mathrm{ml}^{-1}$ for the same drug. Both strains have identical MIC for flucloxacillin $\left(0.2 \mu \mathrm{g} \mathrm{ml}^{-1}\right)$ and GRF (30 $\mu \mathrm{g} \mathrm{ml}^{-1}$ protein). Results are given as the mean \pm S.D. $(n=3)$.

Table 4. Partition coefficients $(P)$ of various antibiotics

\begin{tabular}{ll}
\hline Antibiotic & PPMN/KRP \\
\hline Penicillin G & $0.30 \pm 0.06^{1}$ \\
SMX & $1.7 \pm 0.2$ \\
TMP & $4.1 \pm 0.6$ \\
Tetracycline & $7.1 \pm 0.7$ \\
\hline
\end{tabular}

\footnotetext{
${ }^{1}$ mean \pm S.D., $n=12$ (four samples from three normal donors).
} 
tetracycline) showed a partition coefficient greater than 1. Only the partition of penicillin $G$ was in favour of the extracellular space. The water volume of the PMN as assayed with this method was $257 \pm 23 \mathrm{fl}$ (11 healthy donors), with an osmolality of 289 mosmoles of the buffer used.

\section{DISCUSSION}

The administration of sulfonamides alone or of SMX/TMP for prophylaxis and treatment of infections in CGD is now a generally accepted procedure. The efficacy of SMX/TMP can be partly explained by its broad spectrum of bactericidal activity (39), and by selective intestinal decontamination. Many anaerobic bacteria are not affected, so that changes in the intestinal flora are minimal and are mostly restricted to the elimination of $S$. aureus and of Enterobacteriaceae $(22,23,32)$ to which $C G D$ patients are unduly susceptible. However, the striking clinical success of SMX/TMP has given rise to speculations that these drugs might act in a way other than the classical antibiotic one; that is, other than by inhibition of tetrahydrofolate biosynthesis. The following alternative modes of action have been considered.

\section{INHIBITION OF BACTERIAL CATALASE}

Inhibition of bacterial catalases by sulfonamides would permit the release of peroxide generated by bacteria, thus rendering them susceptible to killing even by CGD-PMN. Johnston et al. (18) however, found no inhibition of bacterial or bovine catalases by sulfisoxazole. Our results (Table 1) confirm and extend these observations to SMX/TMP. SMX at $0.4 \mathrm{mM}$ and TMP at 0.07 $\mathrm{mM}$ (corresponding to $120 \mu \mathrm{g} \mathrm{ml}^{-1}$ SMX/TMP (ratio 5:1 by weight) and human serum drawn $3 \mathrm{hr}$ after administration of SMX/TMP showed no significant effect on catalase activity.

\section{IMPROVEMENT OF GRANULOCYTE OXYGEN METABOLISM}

Pyesmany and Cameron (35) reported an SMX/TMP mediated increase of the oxidative metabolism in CGD-PMN. However, this observation was not confirmed by others $(18,42)$. Anderson et al. (2) found no improvement of normal neutrophil respiratory functions by SMX/TMP. Our results also indicate that normal and CGD-PMN do not produce more hydrogen peroxide when SMX/TMP or its metabolites are present, as shown by unaltered oxygen consumption (Table 2), and unaltered superoxide anion production (Table 3 ) of resting and stimulated cells. Sulfonamides inhibit peroxidases (25). Such action could allow tiny amounts of oxygen radicals to survive inside CGD-PMN and to reconstitute the oxygen-dependent killing mechanisms. If enough perhydroxy radical $\left(\mathrm{HO}_{2}\right)$ was generated, nonenzymatic oxidation of NADPH could occur and create a self-perpetuating chain reaction (41). This possible mode of action of SMX/TMP seems also not to take place as shown by unaltered superoxide anion production (Table 3). Also SMX/TMP or its metabolites present in human serum after SMX/TMP administration per se do not directly reduce oxygen to hydrogen peroxide (Fig. 1c).

\section{SYNERGISTIC ACTION OF SMX/TMP WITH GRF}

The effectiveness of SMX/TMP could be due to a synergistic action with the intact nonoxygen-dependent killing mechanisms of CGD-PMN (21). Such a synergism was reported for nafcillin by Warren and Gray (43) and by Friedman and Warren (14). These authors suggested that nafcillin, even at low concentrations, may profoundly affect the integrity of the bacterial cell wall, leading to increased susceptibility to cell wall lytic enzymes of the phagocyte. Root et al. (37) showed that subinhibitory (sub-MIC) concentrations of penicillin $G$ increased susceptibility of $S$. aureus to killing by nonoxygen-dependent bactericidal mechanisms. Using electron microscopy, Klainer and Perkins (20) demonstrated changes on the surface of $S$. aureus organisms when these were pretreated with subbactericidal concentrations of penicillins or SMX/TMP. Evidence for inhibition of cell wall synthesis by blockade of folate metabolism was also provided by Daschner (8) and by Dulaney and Marx (12). We investigated a possible synergism between the nonoxygen-dependent killing mechanisms of PMN and subbactericidal antibiotic concentrations using two strains of $S$. aureus (SMX/TMP resistent, and SMX/TMP susceptible). The nonoxygen-dependent killing mechanisms are located in the granules, which burst into the vacuole formed after phagocytosis (44). Incubation of staphylococci with 1.0 MIC GRF from normal granulocytes and 1.0 MIC flucloxacillin was bactericidal while the combination of 1.0 MIC GRF with 1.0 MIC SMX/TMP had no killing effect (Fig. 2). From these data it seems likely that sublethal concentrations of SMX/TMP equally fail to improve killing of bacteria by the nonoxygen-dependent mechanisms of CGD-PMN. However, as the above experiments were performed with disrupted cells the normal vacuole environment might not have been completely mimicked. It is planned therefore to extend our studies of synergism to intact normal and CGDPMN which have taken up SMX/TMP-pretreated bacteria into vacuoles.

\section{CELL PENETRATION AND ACCUMULATION OF SMX/TMP}

SMX/TMP is very effective in the treatment of infections caused by intracellular microorganisms such as Pneumocystis carinii and Toxoplasma gondii. This suggests that its unique beneficial effect in CGD patients might be related to penetration and accumulation of the drug inside the leukocyte. This was tested experimentally by determining PMN/buffer partition coefficients. We found the partition coefficients of SMX/TMP and Tetracycline to be greater than 1 (Table 4), which seems to indicate not only cell membrane penetration, but also concentration. Berneis and Boguth (5) obtained a red blood cell/medium partition coefficient of 1.3 for SMX and 4.2 for TMP, which agrees with our observations. On the other hand, we found cell-associated concentrations of penicillin $G$ of less than a third of the extracellular levels. Mandell (27) also showed that penicillin $G$ did not penetrate the PMN leukocyte. This could explain the penicillin resistance of phagocytosed bacteria reported by Holmes et al. (15) in 1966.

Partition along pH gradients may be the important mechanism for directing antibiotics like TMP into the cell. As intracellular $\mathrm{pH}$ in granulocytes is about 7.2 (31) and intravacuolic $\mathrm{pH}$ of normal and CGD-PMN is even lower between 4.5 and 5.0 (16) weak acids, such as penicillin, would be excluded from the more acidic cell interior, whereas weak bases such as trimethoprim and tetracyclines would be accumulated. This explanation, however, does not hold for sulfamethoxazole, which is slightly acidic.

\section{REFERENCES AND NOTES}

1. Amano, D., Kagosaki, Y., Nitta, Y., Kobayashi, Y., Higaki, T., and Usui, T.: Sulfamethoxazole/trimethoprim (SMX/TMP) in the treatment of chronic granulomatous disease. Jap. J. Pediatr., 30: 1543 (1977).

2. Anderson, D., Granow, G., Oosthuizen, R., Theron, A., and von Remsburg, A. J.: Effects of sulfamethoxazole and trimethoprim on human neutrophil and lymphocyte function in vitro: in vivo effects of cotrimoxazole. Antimicrob. Agents Chemother., 17: 322 (1980).

3. Babior, B., Kipnes, R., Curnutte, J.: Biological defense mechanisms. The production by leukocytes of superoxide, a potent bactericidal agent. J. Clin. Invest., 52: 741 (1973).

4. Baggiolini, M.: (personal communication).

5. Berneis, K., and Boguth, W.: Distribution of sulfonamides and sulfonamide potentiators between red blood cells, proteins and aqueous phases of the blood of different species. Chemotherapy, 22: 390 (1976).

6. Böyum, A.: Isolation of lymphocytes, granulocytes and macrophages. Scand. J. Immunol., 5 (Suppl.5): 9 (1976).

7. Bujak, J. J., Ottesen, E. A., Dinarello, C. A., and Bremer, V. J.: Nocardiosis in a child with chronic granulomatous disease. J. Pediatr. 83: 98 (1973).

8. Daschner, F.: Inhibition of cell wall synthesis by sulfonamides and trimethoprim Chemotherapy, 22: 12 (1976).

9. Deamer, D. W., Heikila, P. E., Panganamala, R. V., Cohen, G., and Cornwell, D. G.: The alloxan-dialuric acid cycle and the generation of hydrogenperoxide Physiol. Chem. Phys., 3: 426 (1971).

10. Del Rio, L. A., Ortega, M. G., Lopez, A. L., and Gorgé, J. L.: A more sensitive modification of the catalase assay with the Clark oxygen Electrode. Anal. Biochem., 80: 409 (1977).

11. Dewald, B., Baggiolini, M., Curnutte, J. T., and Babior, B. M.: Subcellular localization of the superoxide-forming enzyme in human neutrophils. J. Clin. Invest., 63: 21 (1979). 
12. Dulaney, E. L., and Marx, L. M.: A folic acid linked system in bacterial cell wall synthesis. J. Antibiotics, 24: 713 (1971).

13. Ezer. G., and Soothill. J. F.: Intracellular bactericidal effects of rifampicin in both normal and CGD polymorphs. Arch. Dis. Childhood, 49: 463 (1974).

14. Friedman. H., and Warren. G. H.: Enhanced susceptibility of penicillin resistent staphylococci to phagocytosis after in vitro incubation with low doses of nafcillin. Proc. Soc. Exp. Biol. Med., 146: 707 (1974).

15. Holmes, B., Quie. P. G., Windhorst, D. B., Pollara, B., and Good, R. A.: Protection of phagocytized bacteria from the killing action of antibiotics. Nature, 210: 1131 (1966).

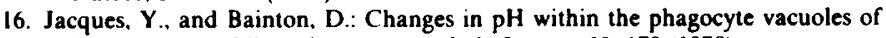
human neutrophils and monocytes. Lab. Invest., 39: 179 (1978).

17. Johnston, R. B., and Baehner, R. L.: Improvement of leukocyte bactericidal activity in chronic granulomatous disease. Blood, 35: 350 (1970).

18. Johnston, R. B., Wilfert, C. M., Buckley, R. H., Webb, L. S., DeChatelet, L. R., and McCall, C. E.: Enhanced bactericidal activity of phagocytes from patients with chronic granulomatous disease in the presence of sulfisoxazole. Lancet, $I$ : 824 (1975).

19. Kaplan, E. L., Laxdal. T., and Quie, P. G.: Studies of PMN from patients with chronic granulomatous disease of childhood: bactericidal capacity for streptococci. Pediatrics, 41: 591 (1968).

20. Klainer, A. S., and Perkins, R. L.: Surface manifestations of antibiotic induced alterations in proteinsynthesis in bacterial cells. Antimicrobial Agents and Chemotherapy, $1:$ : 64 (1972).

21. Klebanoff, S. J., and Clark, R. A.: The neutrophil: function and disorders. NorthHolland, Amsterdam (1978)

22. Knothe, H.: The effect of a combined preparation of trimethoprim and sulfamethoxazole following short-term and long-term administration on the flora of the human gut. Chemotherapy, 18: 285 (1973).

23. Knothe, $H$.: The effect of trimethoprim-sulfonamide, trimethoprim, and sulfonamide on the occurrence of the resistent enterobacteriacceac in human intestinal flora. Infection, 7: 321 (1979).

24. Kobayashi, Y., Amano, D.. Ueda, K., Kagasaki, Y., and Usui, T.: Treatment of seven cases of chronic granulomatous disease with sulfamethoxazole-trimethoprim (SMX-TMP). Eur. J. Pediatr., 127: 247 (1978).

25. Lehrer, R. I.: Inhibition by sulfonamides of the candidacidal activity of human neutrophils. J. Clin. Invest., 50: 2498 (1971).

26. Lorber, B.: Rifampin in chronic granulomatous disease. New Engl. J. Med., 303: 111 (1980).

27. Mandell. G. L.: Interaction of intraleukocytic bacteria and antibiotics. J. Clin. Invest., 52: 1673 (1973)

28. Mandell, G. L., and Hook, E. W.: Leukocyte bactericidal activity in chronic granulomatous disease: correlation of bactericidal hydrogen peroxide production and susceptibility to intracellular killing. J. Bact., J00: 531 (1969).

29. McCrae, W. M.. and Raeburn. J. A.: Chronic granulomatous disease: an attempt to stimulate phagocytic activity. Lancet. I: 1370 (1972).

30. Meynell, G. G., and Meynell, E.: Theory and practice in experimental bacteri- ology, pp. 23-24. (University press, Cambridge, U.K., 1970)

31. Molski, T., Naccache, P., Volip. M., Wolpert, L., and Sha'afi, R.: Specific modulation of the intracellular $\mathrm{pH}$ of rabbit neutrophils by chemotactic factors. Biochem. Biophys. Res. Commun., 94: 508 (1980).

32. Pancoast, S. J., Hyams, D. M., and Neu, H. C.: Effect of trimethoprim and trimethoprim/sulfamethoxazole on development of drug resistent vaginal and fecal floras. Antimicrobial Agents and Chemotherapy, 17: 263 (1980).

33. Philippart, A. I., Colodny, A. H., and Bachner, R. L.: Continuous antibiotic therapy in chronic granulomatous disease: preliminary communication. Pediatrics, 50: 923 (1972).

34. Pitt, J., and Bernheimer, H. P.: Role of peroxide in phagocytic killing of pneumococci. Infection and Immunity, 9: 48 (1974).

35. Pyesmany, A. F., and Cameron, D. L.: Septrin-induced stimulation of granulocyte-metabolism in chronic granulomatous disease. Pediat. Res., 7: 371 (1977).

36. Root, R. K.: Correction of the function of CGD-PMN with extracellular hydrogen peroxide. Clin. Res., 22: 452A (1974).

37. Root, R. K., Isturiz, R., Molavi, A., Metcalf, J. A., and Malech, H. L.: Interactions between antibiotics and human neutrophils in the killing of Staphylocci. J. Clin. Invest, 67: 247 (1981).

38. Rottenburg, $\mathrm{H}$.: The measurement of membrane potential and $\mathrm{pH}$ in cells, organelles and vesicles. Meth. Enzymolog., 55: 547 (1979).

39. Rubin, R. H., and Swartz. M. N.: Trimethoprim-sulfamethoxazole. New Engl. J. Med. 303: 426 (1980).

40. Segal, A. W., and Coade, S. B.: Kinetics of oxygen consumption by phagocytising human neutrophils. Biochem. Biophys. Res. Commun., 84: 611 (1978).

41. Suzuki, Y.. and Lehrer, R. I.: NAD(P)H oxidase activity in human neutrophils stimulated by phorbol myristate acetate. J. Clin. Invest., 66 : 1409 (1980).

42. Tamer, M. A., and Ratzin, K. R.: Effect of trimethoprim and sulfamethoxazole in the therapy of chronic granulomatous disease. Pediat. Res., 10: 404 (1976).

43. Warren, G. H., and Gray, J.: Effect of sublethal concentration of penicillins on the lysis of bacteria by lysozyme and trypsine. Proc. Soc. Exp. Biol. Med., I20: 504 (1965).

44. Zeya, H. I., and Spitznagel, J. K.: Antimicrobial specifity of leukocyte lysosomal cationic proteins. Science, 154: 1049 (1966)

45. The authors thank Dr. Baggiolini for his help in the preparation of the GRF extract. Dr. Böhni and Dr. Crevoisier. Hoffmann-L? Roche, for the determination of MICs and SMX levels, Prof. Hitzig for his encouragement of this study. Mrs. Gubler and Miss Schmid and Miss Vitte for expert technical assistance.

46. The Swiss National Science Foundation (grant number 3.895-0.79) and the Theodor and Ida Herzog-Egli Stiftung is gratefully acknowledged.

47. The present address of Dr. F. Gmünder is: Laborgemeinschan, division of microbiology, Baslerstr. 106, Ch-8048 Zürich, Switzerland.

48. Reprint requests should be addressed to: Dr. R. Seger, Dept. of Paediatrics, University of Zürich, Steinwiesstrasse 75, CH-8032 Zürich, Switzerland

49. Received for publication December 29, 1980.

50. Accepted for publication May 18, 1981 